\title{
Working with People in Prison
}

\section{Robina Courtin ${ }^{1}$}

Published online: 18 January 2018

(C) Springer Science+Business Media, LLC, part of Springer Nature 2018
In early 1996, when I was editor of Mandala, the magazine of the Foundation for the Preservation of the Mahayana Tradition, in Santa Cruz, California, I received a letter from a young Mexican-American, Arturo. He was incarcerated at Pelican Bay, a top-security prison in the north of the state, in his cell $23 \mathrm{~h}$ a day. He told me that he'd read a book by Lama Thubten Yeshe and that he was "moved by the teachings on compassion" and wanted to know more about Buddhism.

Within a year, I had forty prisoners writing to me; Liberation Prison Project developed from there. I'd answer their letters and always send books. I started visiting prisons: giving classes, leading meditations. It was very moving for me. I could see that these prisoners, these human beings, were just like the rest of us but living in pretty dire circumstances.

In the USA, there are more people in prison, in real terms as well as per head of population, than anywhere on earth. It's an accepted fact that the USA has some $5 \%$ of the world population but $25 \%$ of the prison population. In other words, of all the people in the world who live in prisons, a quarter of them live in American prisons. In general, in most states, the sentencing is severe.

In California, where violence among the gangs on the streets is intense, in the state government's attempts to curb crime, there is a law that demands that a person who has been found guilty of a felony for the third time will receive a mandatory sentence of what's referred to as " 25 -to-life": of a minimum of 25 years and a maximum of a life sentence.

Arturo was 20 when he wrote to us, fresh from leaving the prison gangs - a courageous decision in prison, I tell you. He'd joined the gangs on the street when he was 11 . He had been imprisoned since he was 12 , first in juvenile prisons and then, when he was 16, after being tried as an adult, he was sentenced to three terms of 25 -to-life for attempted murder-

Robina Courtin

robinacourtin@mac.com; http://www.robinacourtin.com/

FPMT, 1632 SE 11th Street, Portland, OR 97214, USA effectively gang fights; he's never killed anyone, or dealt in drugs.

It seems that even though crime has decreased overall in the USA since the tough-on-crime attitude of the 1980 s, the prison population has increased hugely. Because of this, there is terrible sense of hopelessness among prisoners. So many have open-ended long sentences that often mean 20 or 30 years in prison before they are allowed to apply for parole-if at all. And then, of course, there are those on death row.

It seems to me that this very condition is the reason many of the prisoners I met over the years who are helped by Liberation Prison Project are such good practitioners. (I handed over the running of the project in 2009 after 14 years to a colleague in Sydney, although I continue to have contact with many friends in prison.) Many of them - on death row or serving life sentences-won't ever get out of prison. They are the ones who realize that they cannot change their situation, but they can change their mind.

I read the memoir of a woman in Florida who with her husband was wrongly accused of murdering two policemen and who spent 17 years in prison - 12 of them on death rowin what we can only imagine is a nightmarish scenario; her husband was even executed. She said that finally she realized that she couldn't change anything - "but they couldn't take my mind from me. So I decided: I am not a prisoner, I am a monk; I am not in a cell, I'm a cave."

This is Buddha's teaching, isn't it? But the irony for most of us is that even though we are not in prison, we often get overwhelmed by our circumstances, become victims of them, blaming them. My friends in prison don't have a choice; their backs are against the wall. They must change their mind; otherwise, they go mad.

In a letter to Arturo in reply to his, Lama Zopa Rinpochemy teacher and the head of the FPMT - told him that "your prison is nothing in comparison with the inner prison of ordinary people" - and that's us! "The prison of attachment, the prison of anger, the prison of depression..." My friends in prison know this to be true. 
What became clear to me from the beginning was that the vast of majority of prisoners who wrote to us - and that was our main contact with prisoners-were working class, uneducated, often from gangs who knew only violence, had few friends or family, and no money. They were imprisoned for street crime, often drug-related. And because of the adoration of guns in the USA, violent crimes that brought death were common. It was rare to receive a letter from a person who had committed a white-collar crime or had an education.

What is also interesting - and I fail to understand whyeven though there are huge numbers of women in prisons in the USA, I would say that not even $1 \%$ of the 25,000 people who wrote to us in the 14 years I was running the project were women.

One of our main programs in our efforts to help prisoners was to provide them with books to read and study and, crucially, a mentor to communicate with via letters. The country is vast and the number of prisons is overwhelming. It was impossible for us to visit every one. And anyway, you would visit a prison once and then return a month later and all the men would have been moved to other prisons.

So, we developed a system that was by far the most effective way to help as many people as possible. At one point, we had a team of 200 mentors worldwide and were receiving a thousand letters every month. A prisoner would write his first letter and we would reply briefly and send a book. If he wrote again, we'd write a longer letter and send another book. If he wrote a third time, we'd assign him to a mentor. This system is still in place.

We also received and paid for their phone calls. And we offered Refuge and the Five Lay Vows, as well as the Bodhisattva Vows, to them on the phone, as well as in person.

Many would go further in their studies and practice; but many didn't: but they got so much from the communication, just from having a friend. Often, it was the first time they'd had contact with a kind person, one who listened to their problems, who gave advice, and who, crucially, would give inspiration, encouragement, and kind words. One young man said he was taken into town to visit the dentist. The nurse, as is usual, casually asked him how he was. He said he burst into tears - so rare is it in prison, or in the lives of many of these men, to ever hear a kind word.

And we sent books, thousands of books. We fortunate, educated people not living in prison totally take books for granted. We have shelves of them and rarely read them. On the other hand, these men in prison, who had nothing, were hungry for books, for information, and for education. Often, too, I could see from their letters over the years that these books not only informed them about the Buddhadharma but they also helped educate them. Many had never read a book in their lives.

One Puerto Rican former gangster told me that his "copy of Lama Yeshe's book was worn thin." For us, one or two people might read our books. For them, ten, twenty, or thirty people would read it.

And the other tool we used was a 16-page newsletter six times a year. The benefit of this was amazing. There are these men - in these garbage-dump environments, often treated like animals, or surrounded by immense violence, with no like-minded people at all, or derided for their Buddhist practice - reading about other prisoners throughout the country, as well as in Australia and other countries, people just like them. It gave them so much courage; they weren't alone. They had sangha. They read the teachings and each other's poetry, short stories, and letters about their experiences and saw each other's art. They loved painting pictures: of all kinds of things, but especially the buddhas. Their art was amazing. We also offered them Mandala magazine. They lived for these treasures arriving in their cells.

For me, the experience of working with these human beings was inspirational. "Practice" takes on another whole level of reality. One of the first men I met in person, a friend of Arturo's and a former gangster, Richie, told me in his letters during our first year of correspondence how he was very laid back, "but when I get angry I get really angry." He had killed three men on the streets; this is common among the gangs. There he was behind glass in the top-security prison, covered in his tattoos - it's all prison art, they proudly tell me! - speaking to me via a telephone. "How's your anger, Richie?" I asked, smiling. He blushed beneath his tattoos and confessed that he'd had a fight with his cellmate that morning and "put his head down the toilet. But," he said, "I took it out again!" Then he had the guy thrown out of his cell—and sat down and did his meditation on Tara! All the Latinos love Tara!

That's practice! I thought. It's relative, isn't it? He didn't kill a fourth person.

My Puerto Rican friend, Timothy, told me in his first letter that he'd heard about how you could get spiritual powers from meditation. He was very excited! "Then I could harm my enemies," he thought. "But I experienced joy instead! And," he added, "there was this green light in my cell. I didn't know whether it was internal or external, but I knew it was feminine." From his Buddhist studies, he discovered that "her name was Tara."

One of our biggest obstacles in the beginning, especially in our efforts to visit prisons, was the bureaucracy, but also the many fundamentalist Christian chaplains who didn't approve of us. In the late 1990s, I went to Texas to visit several prisonsafter much back and forth to get permission - but remembered one man in another prison who would have been devastated if he'd heard that I'd come to Texas but hadn't visited his prison. I rang his chaplain in the hope that he'd allow a quick visit. The moment he heard "Buddhist" he said, "We don't need people like you here," and hung up the phone.

Another man in Texas, on death row, wanted me to be there when they killed him. But the fundamentalist Baptist chaplain was very clear: "You don't believe in God so you're not religious. And anyway you're only a nun." That was the end of that, 
even though Texas law approves of Buddhism as a religion. (His life sentence was later commuted.)

There are many Buddhist volunteer chaplains now, so things are changing, I'm sure.

Many of the prisoners who wrote to us didn't necessarily become Buddhist; and some even wrote and thanked us and said that they were going back to their own faith, Christian or Muslim. We'd always write back and rejoice. My main wish from the beginning was not to make people Buddhist. We used Buddhist tools, no question - that was our expertisebut my wish was to give the prisoners kindness and respect as human beings, to give them confidence in their own marvelous potential, and to give them the courage to know that they could transform their minds, find fulfillment-and help others.

So many of them talk about how they help those worse off than themselves. My friend on death row in Kentucky,
Mitchell, is a dear friend and mentor to many of the other forty men he lives with. One of them, he told, "thinks of torture all the time." Mitchell is his dearest friend; he understands him, takes care of him, and protects him. Richie, the former gangster, wrote about looking after his old Alzheimer-suffering cellmate: chopping up his food so his toothless friend can eat it, cutting his toenails for him, and cleaning up his shit.

I saw Arturo in the summer of 2017, near Los Angeles. He came to visit me: he is finally out of prison. He has spent the past 20 years getting a high school education, studying languages, and practicing a spiritual path. Now he's 41 , going gray, and still delighted to be among the lucky few of the California prisoners able to find a kind lawyer to work pro bono for them to navigate their release. I am so happy for him!

And Mitchell on death row? "I'm ready for that electric jolt!" he told me. He has asked me to be with him when he dies. I will be honored to do so. 